\title{
AN IN VIVO PYELONEPHRITIS ASSAY FOR SCREENING THERAPEUTIC AGENTS
}

\author{
Elizabeth H. Thiele \\ Merck Institute for Therapeutic Research \\ Rahway, New Jersey 07065, U. S. A.
}

(Received for publication August 27, 1973)

\begin{abstract}
Eighty to $100 \%$ of mice stressed with an intraperitoneal dose of $200 \sim 240 \mathrm{mg}$ bromoethylamine hydrobromide (BEA)/ $\mathrm{kg}$ and infected intraveneously 72 hours later with Proteus mirabilis, Pseudomonas, Escherichia coli or Serratia host large numbers of bacteria in their kidneys $3 \sim 4$ days post-infection. If death (probably due to uremic poisoning) does not intervene, the infection lasts for weeks. The therapeutic effects of carbenicillin and ampicillin were tested in this pyelonephritis model. Carbenicillin was effective against Pseudomonas; ampicillin had an effect against $P$. mirabilis, but neither carbenicillin nor ampicillin was effective against Serratia-induced pyelonephritis.
\end{abstract}

While many experimental pyelonephritis models have been proposed ${ }^{1201}$ they are for technical reasons either most reproducible in the laboratories sponsoring them or are not suitable for routine assay work. The pyelonephritis model proposed in this paper, although based on the old idea of preliminary kidney damage, has the advantages of being technically simple, of having less than a $1 \%$ mortality due to preparational causes, of being reproducible in routine evaluations of antibiotics, and can be used in studies for host responses where the kidneys have been damaged by a prior bacterial kidney infection.

The model is based on the observations that 2-bromoethylamine hydrobromide (BEA) causes papillary necrosis of the kidney ${ }^{14,21,22,23)}$. FUWA ${ }^{14)}$ found that rats given a subcutaneous injection of BEA developed a localized pathology limited to the inner medulla. MURRAY, et al. ${ }^{221}$ found that after an intravenous injection of BEA complete necrosis of the rat papilla took place between 4 and 7 days with the dead papilla being sequestered by 21 days. Moreover, HiLl, et al. ${ }^{21}$ also found that the progressive pathology of the papillary region coincided with a defect in the concentrating ability of the kidney, a rise in serum urea nitrogen, and a tubular atrophy that developed secondarily to the papillary damage. KAYE and $\mathrm{RoCHE}^{24}$ and RoLAND, et al. ${ }^{25)}$ demonstrated that kidney infections correlated with decreased urinary concentrating ability. From the above papers it was reasoned that if the mouse kidney was susceptible to BEA damage without a subsequent rise in blood urea nitrogen (BUN) then the kidney might host a bacterial population without depressing the host defenses so that a bacterial invasion of tissues other than the kidney occurs. The data given below show that mice stressed with BEA $3 \sim 4$ days prior to intravenous infection with different bacterial species results in a strictly localized kidney infection. This infection can persist for many weeks providing a BEA-bacterial induced uremic death does not intervene. It has further been shown that carbenicillin is effective against a Pseudomonas kidney infection, that ampicillin has some therapeutic value against a $P$. mirabilis pyelonephritis but that neither antibiotic was effective against a Serratia-induced kidney infection. 


\section{Materials and Methods}

In Vitro Studies. Brain heart infusion broth (BHI) was used for all cultures and diluents. Viable bacterial counts were done on BHI agar with $10 \%$ taurocholate for Proteus mirabilis (MB 3125) and without taurocholate for Pseudomonas strain MB 2836 and Serratia strain MB 2887; LEVINE's EMB agar was used with Escherichia coli, MB 2894 and MB 2896. Antibiotic susceptibility tests to determine the minimal inhibitory concentration were done by the standard $2 \mathrm{ml}$, two-fold dilution assay with a final bacterial concentration of $10^{5}$ cells $/ \mathrm{ml}$. The MIC for the organisms and antibiotics used is given in Table 1.

In Vivo Studies. Taconic Farms female mice $(14 \sim 16 \mathrm{~g})$ were injected intraperitoneally (i.p.) with $200 \sim 240 \mathrm{mg} / \mathrm{kg}$ of BEA and 72 hours later mice were infected intravenously

Table 1. MIC of carbenicillin and ampicillin against five bacterial cultures

\begin{tabular}{l|c|c}
\hline \multirow{2}{*}{ Organism } & \multicolumn{2}{|c}{ MIC in $\mu \mathrm{g} / \mathrm{ml}$} \\
\cline { 2 - 3 } & Carbenicillin & Ampicillin \\
\hline P. mirabilis 3125 & 0.4 & 0.2 \\
Pseudomonas 2836 & 25 & $>100$ \\
Serratia 2887 & 50 & $>100$ \\
E. coli 2894 & 3.0 & 50 \\
E. coli 2896 & 6.0 & $>100$ \\
\hline
\end{tabular}

Numbers refer to the Merck stock culture collection. (i.v.) with an aliquot of a 16 18 hour broth culture. Initial experiments using infection times of day 1 through 7 after BEA treatment showed that infecting at 72 hours post-BEA stress gave the most consistent number of infected kidneys. BEA titrations showed that less than $175 \mathrm{mg} / \mathrm{kg}$ resulted in low morbidity while more than $300 \mathrm{mg} / \mathrm{kg}$ resulted in excess mortality of infected mice. Uninfected mice were not killed by $350 \mathrm{mg}$ BEA $/ \mathrm{kg}$, nor did BEA stressed but non-infected mice develop kidney infections when held throughout the experiments in cages with the BEA-stressed and infected animals.

Viable bacterial population in the blood and kindeys and other tissues was measured as follows: Heart blood was drawn and the mouse was killed by neck dislocation. Liver, spleen and kidneys were excised and homogenized in $10 \mathrm{ml}$ BHI. Bladders were washed with $2 \mathrm{ml}$ BHI broth $2 \sim 3 \times$ and the combined washes were brought to $10 \mathrm{ml}$ and aliquots plated. Blood, homogenates, bladder washes and broth dilutions of these specimens $(0.1 \sim 0.3 \mathrm{ml})$ were spread on agar plates. After 48 hours at $37^{\circ} \mathrm{C}$ the number of colonies on duplicate plates at different dilutions were multiplied by the dilution factor and recorded as the number of bacterial cells/organ or $\mathrm{ml}$ of blood.

In general, the lowest measurable bacteria/organ was 100 , i.e., kidney/10 ml homogenate and $0.1 \mathrm{ml}$ plated giving no colonies would be $<100$ cells/kidney. However, if $0.1 \mathrm{ml}$ of the homogenate produced growth in $10 \mathrm{ml}$ of broth the kidney is presumed to contain at least 100 cells/kidney. Blood urea nitrogen (BUN) was determined by Mr. B. Lopez-RAmos using modification of the standard chemical method ${ }^{26)}$.

\section{Results}

The rate and extent of a bacterial infection after an intravenous bacterial inoculation in BEA-stressed mice was determined by a bacteriological examination of the blood, kidneys, liver and spleen at different times post-inoculation. Table 2 gives the data from a representative experiment in which $P$. mirabilis was the infecting agent. From the data it is obvious that while at 2 hours post-inoculation both controls and BEA-stressed mice had a similar microbial kidney flora by 6 hours post-inoculation the bacteria in the kidneys of BEA-stressed mice had increased by 2 logs over the number of bacteria found in the kidney of the infected controls. From day +1 post-inoculation onward, the majority of the kidneys of the BEA-stressed group host large microbial populations. This is in contrast to the infected controls where in the 
Table 2. Average recovery of $P$. mirabilis from 10 mice at various times after infecting normal and BEA-treated mice with $10^{6}$ cells.

Average number cells per tissue/number of positive tissues in the averaged 10 mice

\begin{tabular}{|c|c|c|c|c|c|c|c|c|}
\hline \multirow{2}{*}{ Post infection } & \multicolumn{2}{|c|}{ Kidneys } & \multicolumn{2}{|c|}{ Blood $/ \mathrm{ml}$} & \multicolumn{2}{|c|}{ Liver } & \multicolumn{2}{|c|}{ Spleen } \\
\hline & Control & BEA & Control & BEA & Control & BEA & Control & BEA \\
\hline hrs. $+2^{*}$ & $10^{2} / 5$ & $10^{2} / 5$ & $380 / 5$ & $584 / 5$ & $10^{5} / 5$ & $10^{5} / 5$ & $10^{3} / 5$ & $10^{4} / 5$ \\
\hline+6 & $10^{2} / 6$ & $10^{4} / 7$ & $30 / 10$ & $70 / 9$ & $10^{4 / 10}$ & $10^{5} / 10$ & $10^{4 / 10}$ & $10^{4} / 10$ \\
\hline days +1 & $0 / 0$ & $10^{6} / 10$ & $6 / 4$ & $9 / 7$ & $10^{3} / 10$ & $10^{3} / 10$ & $10^{2} / 9$ & $10^{4} / 10$ \\
\hline$+2 * *$ & $20 / 2$ & $10^{6} / 7$ & $8 / 3$ & $7 / 6$ & $10^{2} / 8$ & $10^{3} / 7$ & $60 / 4$ & $10^{2} / 4$ \\
\hline+3 & $10^{5} / 1$ & $10^{7} / 9$ & $0 / 0$ & $0 / 0$ & $10^{3} / 6$ & $10^{3} / 6$ & $10^{2} / 6$ & $20 / 4$ \\
\hline+4 & $10^{7} / 1$ & $10^{5} / 7$ & & $0 / 0$ & $10^{2} / 3$ & $10^{2} / 3$ & $10^{2} / 6$ & $0 / 0$ \\
\hline+5 & $10^{5} / 1$ & $10^{7} / 9$ & & $9 / 1$ & $10^{2} / 2$ & $10^{3} / 6$ & $20 / 1$ & $40 / 2$ \\
\hline+6 & $10^{4} / 1$ & $10^{7} / 7$ & & $0 / 0$ & $10^{4} / 1$ & $10^{2} / 7$ & $10^{4} / 1$ & $10^{2} / 2$ \\
\hline+7 & $0 / 0$ & $10^{7} / 8$ & & $0 / 0$ & $0 / 0$ & $10^{3} / 2$ & $0 / 0$ & $0 / 0$ \\
\hline+8 & $0 / 0$ & $10^{7} / 8$ & & $0 / 0$ & $0 / 0$ & $0 / 0$ & $0 / 0$ & $0 / 0$ \\
\hline
\end{tabular}

(200 $240 \mathrm{mg} / \mathrm{kg}$ BEA followed 3 days later with $10^{6}$ bacterial cells i.v.)

* Only 5 mice

** Only 9 mice assayed instead of 10 in BEA treated mice

kidneys of only $10 \%$ of the mice was the inoculum able to establish itself and multiply.

In Table 2 it is also evident that neither a bacteremia nor septicemia is the result of a large microbial population in the kidneys of the BEA-stressed animals. It is also evident from Table 2 that while the liver and spleen of these animals contain recoverable $P$. mirabilis organisms the number recoverable is approximately the same in both the BEA-stressed and control groups and relative to the number of bacteria found in the kidneys of BEA-stressed mice is quite small.

Table 3. Bacterial population in kidneys of BEA-stressed mice* at various times after infecting with $4 \times 10^{6}$ cells $E$. coli

\begin{tabular}{|c|c|c|c|c|c|c|c|c|c|c|}
\hline Mouse No. & +2 hrs. & +6 hrs. & +1 day & +2 days & +3 days & +4 days & +5 days & +6 days & +7 days & +8 days \\
\hline 1 & $<100$ & $<100$ & $<100$ & $2 \times 10^{4}$ & 100 & $<100$ & $5 \times 10^{4}$ & $<100$ & $2 \times 10^{3}$ & $<100$ \\
\hline 2 & 150 & 100 & 100 & $10^{5}$ & $2 \times 10^{4}$ & $3 \times 10^{6}$ & $10^{5}$ & $6 \times 10^{6}$ & $2 \times 10^{4}$ & $10^{6}$ \\
\hline 3 & 200 & $2 \times 10^{3}$ & $3 \times 10^{4}$ & $10^{5}$ & $10^{7}$ & $7 \times 10^{6}$ & $10^{5}$ & $2 \times 10^{7}$ & $2 \times 10^{6}$ & $3 \times 10^{6}$ \\
\hline 4 & 200 & $2 \times 10^{3}$ & $3 \times 10^{4}$ & $10^{5}$ & $10^{7}$ & $5 \times 10^{7}$ & $2 \times 10^{7}$ & $4 \times 10^{7}$ & $2 \times 10^{6}$ & $3 \times 10^{7}$ \\
\hline 5 & 600 & $3 \times 10^{3}$ & $10^{6}$ & $10^{5}$ & $10^{7}$ & $16^{8}$ & $6 \times 10^{7}$ & $7 \times 10^{7}$ & $6 \times 10^{7}$ & $3 \times 10^{7}$ \\
\hline
\end{tabular}

\begin{tabular}{c|c|c|c|c|c|c|c|c}
\hline Mouse No. & +13 days & +20 days & Mouse No. & +13 days & +20 days & Mouse No. & +13 days & +20 days \\
\cline { 2 - 8 } 1 & $<100$ & $<100$ & 8 & $2 \times 10^{6}$ & 400 & 15 & $9 \times 10^{6}$ & $3 \times 10^{7}$ \\
2 & $<100$ & $<100$ & 9 & $3 \times 10^{6}$ & $10^{3}$ & 16 & $10^{7}$ & $3 \times 10^{7}$ \\
3 & $<100$ & $<100$ & 10 & $3 \times 10^{6}$ & $4 \times 10^{4}$ & 17 & $6 \times 10^{7}$ & $4 \times 10^{7}$ \\
4 & $<100$ & $<100$ & 11 & $4 \times 10^{6}$ & $6 \times 10^{5}$ & 18 & $6 \times 10^{7}$ & $5 \times 10^{7}$ \\
5 & $<100$ & $<100$ & 12 & $5 \times 10^{6}$ & $4 \times 10^{6}$ & 19 & $8 \times 10^{7}$ & $10^{6}$ \\
6 & 200 & $<100$ & 13 & $5 \times 10^{6}$ & $4 \times 10^{6}$ & 20 & $8 \times 10^{7}$ & $10^{8}$ \\
7 & $5 \times 10^{6}$ & 200 & 14 & $7 \times 10^{6}$ & $7 \times 10^{6}$ & & & \\
\hline
\end{tabular}

* In this experiment, the infected control mice after day +1 were uniformly bacteriological negative as were the blood, liver and spleen of the BEA-stressed and infected mice shown in the table. 
Table 3 gives a representative experiment from a series of experiments done with $E$. coli as the infecting agent. Mice not stressed with BEA prior to infecting with $4 \times 10^{6}$ cells are footnoted in the table since in this particular experiment none of them had detectable $E$. coli in their kidneys. In other experiments, there was an occasional non-BEA-stressed mouse that did have a kidney infection but this was rarely found after day 4 . From the data it can be seen that $E$. coli, like $P$. mirabilis, localizes and becomes established in the kidney by $6 \sim 48$ hours post-infection. Tissues other than kidneys, were examined and were almost uniformly negative after day +1 . Hence, bacteriological data for tissues other than the kidneys indicate that with $E$. coli as with $P$. mirabilis the preparatory method of BEA to induce pyelonephritis results in a kidney localized infection. No subsequent septicemia, bacteremia or bacterial invasion of the liver and spleen was found regardless of the number of bacteria recoverable from the kidneys.

Table 4 shows the effect of an increasing $P$. mirabilis inoculum on the mortality at days post-inoculum and on the number of infected kidneys at day 4, 8 and 11 post-inoculum. From the data, it is apparent that deaths occurred only in the BEA-stressed group and that only BEAstressed mice had consistently high kidney morbidity. While some of the control mice had measurable $(100 \sim 300$ bacteria/kidney) bacteria in their kidneys only two kidneys in the control group $\left(5 \times 10^{7}\right.$ cells on 8 th day post-infection) had a bacterial kidney flora $\left(10^{6}\right.$ and $\left.10^{8}\right)$ comparable to that found in the BEA-stressed animals. It can also be seen from Table 2 that with inoculum of $5 \times 10^{5}$ cells mortality was greatest between the 5 th and the 8 th day, while with

Table 4. Mortality and number of infected kidneys post-infection of $P$. mirabilis

\begin{tabular}{|c|c|c|c|c|c|c|}
\hline \multirow{3}{*}{$\begin{array}{l}\text { Infection with } \\
\text { pre-treated }\end{array}$} & \multicolumn{6}{|c|}{ Number mice dead on day post-infection } \\
\hline & \multicolumn{2}{|c|}{$5 \times 10^{5}$ cells } & \multicolumn{2}{|c|}{$5 \times 10^{6}$ cells } & \multicolumn{2}{|c|}{$5 \times 10^{7}$ cells } \\
\hline & BEA* & - & BEA* & - & BEA* $^{*}$ & - \\
\hline $\mathrm{Day}+1$ & 0 & 0 & 0 & 0 & 0 & 0 \\
\hline 2 & 0 & 0 & 0 & 0 & 15 & 0 \\
\hline 3 & 2 & 0 & 13 & 0 & 11 & 0 \\
\hline 4 & 3 & 0 & 10 & 0 & 11 & 0 \\
\hline Death/Total & $5 / 45$ & $0 / 20$ & $23 / 50$ & $0 / 20$ & $37 / 69$ & $0 / 26$ \\
\hline +Kidneys/Total & $14 / 16^{* * *}$ & $0 / 10$ & $13 / 14$ & $0 / 10$ & $10 / 10$ & $0 / 10$ \\
\hline 5 & 0 & 0 & 0 & 0 & 7 & 0 \\
\hline 6 & 4 & 0 & 0 & 0 & 4 & 0 \\
\hline 7 & 6 & 0 & 2 & 0 & 2 & 0 \\
\hline 8 & 4 & 0 & 0 & 0 & 2 & 0 \\
\hline Death/Total & $14 / 32$ & $0 / 15$ & $2 / 20$ & $0 / 15$ & $15 / 27$ & $0 / 21$ \\
\hline +Kidneys/Total & $10 / 14$ & $0 / 10$ & $18 / 20$ & $0 / 10$ & $20 / 24$ & $3 / 10 * *$ \\
\hline 9 & 0 & 0 & 0 & 0 & - & 0 \\
\hline 10 & 0 & 0 & 0 & 0 & - & 0 \\
\hline 11 & 0 & 0 & 1 & 0 & - & 0 \\
\hline Death/Total & $0 / 11$ & $0 / 10$ & $1 / 8$ & $0 / 10$ & - & $0 / 16$ \\
\hline +Kidneys/Total & $18 / 22$ & $0 / 10$ & $9 / 14$ & $3 / 10^{* *}$ & - & $3 / 16^{* *}$ \\
\hline
\end{tabular}

* Mice received $240 \mathrm{mg} / \mathrm{kg} 3$ days before injection of Proteus mirabilis.

** $<10^{3}$ cells/kidneys (except for 2 mice given $5 \times 10^{7}$ and examined on day +8 ) in contrast to the BEA-treated mice whose + kidneys contained $>10^{3}$ cells/kidney.

*** Right and left kidney examined separately, therefore, a total of 16 kidneys refers to 8 mice, etc. 
$5 \times 10^{6}$ cells most of the mice died at the $3 \mathrm{rd}$ and 4 th day post-infection. Hence, decreasing the infecting dose prolonged life without a corresponding decrease in the number of kidneys infected.

Table 5 gives data for individual mice harvested on the 8th day post-infection. In order to facilitate table reading, the data, wherever possible, have been arranged according to the increasing numbers of bacteria found in the kidneys. It is apparent that BEA-treated, infected animals not only have a much higher morbidity rate than infected control animals but the bacterial populations in the kidneys is also considerably higher. It is also apparent from Table 5 that BUN values do not necessarily correlate with the numbers of bacteria found in

Table 5. P. mirabilis counts in kidneys and BUN values (8th day post-infection)

\begin{tabular}{|c|c|c|c|c|c|c|c|c|}
\hline \multirow{4}{*}{$\begin{array}{c}\begin{array}{c}\text { Infecting } \\
\text { dose }\end{array} \\
\text { Mouse }\end{array}$} & \multicolumn{8}{|c|}{ Bacteria in kidneys $/ \mu \mathrm{g}$ BUN per $100 \mathrm{ml}$ blood } \\
\hline & \multicolumn{4}{|c|}{ BEA treated } & \multicolumn{4}{|c|}{ Infected controls } \\
\hline & \multicolumn{2}{|c|}{$5 \times 10^{6}$} & \multicolumn{2}{|c|}{$5 \times 10^{7}$} & \multicolumn{2}{|c|}{$5 \times 10^{6}$} & \multicolumn{2}{|c|}{$5 \times 10^{7}$} \\
\hline & Kidney & BUN & Kidney & BUN & Kidney & BUN & Kidney & BUN \\
\hline 1 & $<100$ & 24 & $<100$ & 21 & $<100$ & 29 & $<100$ & 15 \\
\hline 2 & $2 \times 10^{3}$ & 21 & $<100$ & 24 & $<100$ & 26 & $<100$ & 18 \\
\hline 3 & $4 \times 10^{3}$ & 51 & $3 \times 10^{5}$ & 26 & $<100$ & 24 & $<100$ & 16 \\
\hline 4 & $3 \times 10^{5}$ & 26 & $4 \times 10^{5}$ & 26 & $<100$ & 23 & $<100$ & 22 \\
\hline 5 & $10^{8}$ & 41 & $2 \times 10^{6}$ & 26 & $<100$ & 16 & $<100$ & - \\
\hline 6 & $10^{8}$ & 25 & $10^{8}$ & 49 & $<100$ & 26 & 200 & 16 \\
\hline 7 & $10^{8}$ & 17 & $10^{8}$ & 140 & $<100$ & 30 & 200 & - \\
\hline 8 & $10^{8}$ & 16 & $2 \times 10^{8}$ & 216 & $<100$ & 23 & $10^{3}$ & 23 \\
\hline 9 & $10^{8}$ & 81 & $2 \times 10^{8}$ & 192 & 100 & 20 & $2 \times 10^{6}$ & 21 \\
\hline 10 & $10^{8}$ & 270 & $4 \times 10^{8}$ & 81 & 300 & 21 & $10^{8}$ & 26 \\
\hline 11 & - & - & $4 \times 10^{8}$ & 240 & - & - & - & - \\
\hline 12 & - & - & $10^{9}$ & 190 & - & - & - & - \\
\hline
\end{tabular}

$\mathrm{BUN}$ values for uninfected control animals with and without BEA were $18 \sim 30 \mu \mathrm{g} \mathrm{BUN} / 100 \mathrm{ml} \mathrm{blood}$.

Table 6. Proteus mirabilis recovered from moribund mice*

\begin{tabular}{|c|c|c|c|c|c|c|}
\hline \multirow{2}{*}{$\begin{array}{l}\text { Infecting } \\
\text { dose }\end{array}$} & \multicolumn{5}{|c|}{ Number bacteria/organ or $\mathrm{ml}$ of blood } & \multirow{2}{*}{$\begin{array}{c}\mu \mathrm{g} / 100 \mathrm{ml} \\
\text { Blood BUN }\end{array}$} \\
\hline & Blood & Liver & Spleen & Bladder** & Kidney & \\
\hline $5 \times 10^{7}$ & 10 & $10^{3}$ & $10^{2}$ & - & $10^{8}$ & 140 \\
\hline $5 \times 10^{7}$ & 50 & $10^{4}$ & $10^{2}$ & - & $10^{8}$ & 216 \\
\hline $5 \times 10^{7}$ & $<10$ & $<10^{2}$ & $<10^{2}$ & $<10$ & $10^{8}$ & 192 \\
\hline $5 \times 10^{7}$ & 10 & $10^{5}$ & $<10^{2}$ & 10 & $10^{8}$ & 81 \\
\hline $5 \times 10^{7}$ & 190 & $10^{5}$ & $10^{3}$ & - & $10^{8}$ & 244 \\
\hline $5 \times 10^{7}$ & 20 & $10^{5}$ & $10^{2}$ & $10^{5}$ & $10^{9}$ & 190 \\
\hline $5 \times 10^{6}$ & 10 & $10^{6}$ & 50 & $10^{5}$ & $10^{8}$ & 270 \\
\hline $5 \times 10^{5}$ & 10 & $10^{6}$ & $10^{3}$ & $10^{5}$ & $10^{8}$ & 278 \\
\hline $5 \times 10^{5}$ & 10 & $<10^{2}$ & $<10^{2}$ & - & $10^{8}$ & 187 \\
\hline
\end{tabular}

* The data from non-moribund mice are not included since in all cases $<100$ cells were found in liver, spleen or bladder and $<10$ cells $/ \mathrm{ml}$ were found in the blood.

** Bladders were empty and collapsed. 
Table 7. The influence of diuresis on morbidity and mortality of a BEA-Proteus mirabilis* pyelonephritis (Non-BEA-stressed controls were negative)

\begin{tabular}{|c|c|c|c|c|c|c|}
\hline \multirow[b]{3}{*}{ Kidney } & \multicolumn{6}{|c|}{ Number cells/right \& left kidneys on the 7 th day post-infection } \\
\hline & \multicolumn{2}{|c|}{ No diuresis } & \multicolumn{2}{|c|}{$\begin{array}{l}\text { Diuresis on day } \\
-3,-2,-1\end{array}$} & \multicolumn{2}{|c|}{$\begin{array}{l}\text { Diuresis on day } \\
0,+1,+2\end{array}$} \\
\hline & Right & Left & Right & Left & Right & Left \\
\hline \multirow[t]{7}{*}{ Mouse No. } & $<100$ & $<100$ & $<100$ & $<100$ & 400 & $10^{3}$ \\
\hline & $<100$ & $10^{6}$ & $<100$ & $10^{4}$ & $10^{3}$ & $10^{3}$ \\
\hline & $10^{3}$ & $10^{3}$ & $<100$ & $10^{6}$ & $10^{7}$ & $10^{6}$ \\
\hline & $10^{5}$ & $10^{4}$ & $<100$ & $10^{6}$ & $10^{7}$ & $3 \times 10^{7}$ \\
\hline & $10^{5}$ & $10^{8}$ & $10^{8}$ & $10^{8}$ & $10^{8}$ & $10^{8}$ \\
\hline & $10^{7}$ & $10^{6}$ & ND & ND & ND & ND \\
\hline & $10^{7}$ & $10^{8}$ & ND & ND & ND & ND \\
\hline \multirow{3}{*}{$\begin{array}{l}\text { Deaths/Total } \\
\text { Positive Kidney/Total }\end{array}$} & \multirow{2}{*}{\multicolumn{2}{|c|}{$\begin{array}{r}7 / 22 \\
11 / 14\end{array}$}} & \multirow{2}{*}{\multicolumn{2}{|c|}{$\begin{array}{l}4 / 22 \\
5 / 10\end{array}$}} & \multicolumn{2}{|c|}{$5 / 20$} \\
\hline & & & & & \multicolumn{2}{|c|}{$10 / 10$} \\
\hline & \multicolumn{6}{|c|}{ Number cells/both kidneys on days +15} \\
\hline \multirow{10}{*}{ Mouse No. } & \multicolumn{2}{|c|}{$<100$} & \multicolumn{2}{|c|}{$>10^{3}$} & \multicolumn{2}{|c|}{$<100$} \\
\hline & \multicolumn{2}{|c|}{$<100$} & \multicolumn{2}{|c|}{$10^{6}$} & \multicolumn{2}{|c|}{$<100$} \\
\hline & \multicolumn{2}{|c|}{$10^{3}$} & \multicolumn{2}{|c|}{$10^{6}$} & \multicolumn{2}{|c|}{$10^{6}$} \\
\hline & \multicolumn{2}{|c|}{$10^{5}$} & \multicolumn{2}{|c|}{$10^{6}$} & \multicolumn{2}{|c|}{$10^{6}$} \\
\hline & \multicolumn{2}{|c|}{$10^{6}$} & \multicolumn{2}{|c|}{$10^{7}$} & \multicolumn{2}{|c|}{$10^{8}$} \\
\hline & \multicolumn{2}{|c|}{$10^{8}$} & \multicolumn{2}{|c|}{$10^{7}$} & \multicolumn{2}{|c|}{$10^{8}$} \\
\hline & \multicolumn{2}{|c|}{-} & \multicolumn{2}{|c|}{$10^{7}$} & & \\
\hline & & & & & & \\
\hline & & & & & & \\
\hline & & & & & & \\
\hline Deaths/Total** & & & & & & \\
\hline Positive Kidney/Total & & & & & & \\
\hline
\end{tabular}

* $2 \times 10^{6} P$. mirabilis cells given i. v. on day 0 . Mice were stressed with BEA on day -3 .

** Not cummulative, $i . e$. deaths from day +7 to day +15 .

the kidneys, i.e., mice 5 through 10 of the BEA-treated group given $5 \times 10^{6}$ cells all had $10^{8}$ cells/kidneys but the BUN values varied from a normal range of $16 \sim 30$ to a high level of 80 and $270 \mu \mathrm{g} \mathrm{BUN} / 100 \mathrm{ml}$ blood. Moreover, two non-BEA-stressed animals (infected controls) had normal BUN values but hosted $2 \times 10^{6}$ and $10^{8}$ cells/kidneys. Hence while the presence of a large bacterial kidney population seems to be a prerequisite for a high BUN value the converse is not true, i.e., a large bacterial kidney population does not au prior result in elevated BUN values.

When BUN values and bacteriological studies were done on moribund mice (Table 6) it was found that all BUN values were abnormally elevated and the kidney microbial counts were also high. However, even on moribund mice, some examined at death, most of the animals had relatively few bacteria in their blood and spleen while the number of bacteria found in the liver and bladder was variable and two or more logs less than the number of cells found in the kidneys. 
Table 8. Carbenicillin or ampicillin therapy in BEA*-stressed mice infected with Proteus mirabilis or Pseudomonas

\begin{tabular}{|c|c|c|c|c|c|c|c|c|c|}
\hline \multirow{3}{*}{$\begin{array}{l}\mathrm{R} \times 2 \mathrm{mg} / \mathrm{dose}^{* *} \\
\text { Proteus mirabilis }\end{array}$} & \multicolumn{9}{|c|}{ Bacteria recovered from kidneys on different post infection days } \\
\hline & \multicolumn{3}{|c|}{ Ampicillin } & \multicolumn{3}{|c|}{ Carbenicillin } & \multicolumn{3}{|c|}{ Controls } \\
\hline & Day +5 & Day +8 & Day +11 & Day +5 & Day +8 & Day +11 & Day +5 & Day +8 & Day +11 \\
\hline Mouse No. 1 & $<100$ & $<10^{2}$ & $10^{3}$ & $10^{5}$ & $<10^{2}$ & $10^{6}$ & $<10^{2}$ & $10^{8}$ & ND \\
\hline 2 & & $10^{3}$ & $10^{7}$ & $10^{7}$ & $3 \times 10^{3}$ & $10^{6}$ & $10^{5}$ & $10^{8}$ & ND \\
\hline 3 & & $10^{3}$ & $10^{8}$ & $10^{8}$ & $10^{7}$ & $10^{8}$ & $10^{6}$ & $10^{8}$ & ND \\
\hline 4 & & $10^{7}$ & $10^{8}$ & $10^{8}$ & $10^{8}$ & $10^{8}$ & $10^{8}$ & ND & ND \\
\hline 5 & $10^{6}$ & $10^{8}$ & $10^{8}$ & $10^{9}$ & $10^{8}$ & $10^{8}$ & $10^{8}$ & ND & ND \\
\hline Deaths***/Total & $0 / 28$ & $3 / 23$ & $5 / 15$ & $2 / 28$ & $6 / 21$ & $5 / 10$ & $12 / 28$ & $5 / 11$ & $3 / 3$ \\
\hline Pseudomonas & Day +4 & Day +9 & Day +15 & Day +4 & 4 Day +9 & $\mathrm{Day}+15$ & Day +4 & Day +9 & Day +15 \\
\hline Mouse No. 1 & $<10^{2}$ & $<10^{2}$ & $<10^{2}$ & $<10^{2}$ & $<10^{2}$ & $<10^{2}$ & $10^{4}$ & $<10^{2}$ & $10^{7}$ \\
\hline 2 & $10^{4}$ & $<10^{2}$ & & $10^{3}$ & & & $10^{6}$ & $10^{6}$ & $10^{7}$ \\
\hline 3 & $10^{5}$ & $10^{5}$ & & $10^{7}$ & & & $10^{6}$ & $10^{7}$ & ND \\
\hline 4 & $10^{6}$ & $10^{8}$ & $10^{7}$ & $10^{8}$ & & & $10^{8}$ & $10^{7}$ & ND \\
\hline 5 & $10^{6}$ & $10^{8}$ & $10^{8}$ & $10^{8}$ & $10^{7}$ & & $10^{8}$ & $10^{8}$ & ND \\
\hline Deaths/Totals & $6 / 28$ & $6 / 17$ & $1 / 6$ & $3 / 28$ & $5 / 20$ & $1 / 10$ & $12 / 28$ & $4 / 11$ & $0 / 2$ \\
\hline
\end{tabular}

* Non-BEA-stressed mice had $0 \%$ mortality and morbidity.

** $\mathrm{Rx}$ given to all mice at 0 and 24 hours post infection plus one hour prior to harvest.

*** Deaths not cummulative i.e., day 0 to +5 and +5 to +8 and +8 to +15 .

Table 9. Carbenicillin and ampicillin therapy in mice infected with $5 \times 10^{6}$ cells Serratia

\begin{tabular}{|c|c|c|c|c|c|c|}
\hline \multirow{3}{*}{$\begin{array}{l}\mathrm{Rx} 2 \mathrm{mg} / \text { dose* }^{*} \\
\text { Mice pre-stressed }\end{array}$} & \multicolumn{6}{|c|}{ Cells/kidneys on days 4 and 8 post infection } \\
\hline & \multicolumn{2}{|c|}{ Carbenicillin } & \multicolumn{2}{|c|}{ Ampicillin } & \multicolumn{2}{|c|}{ Controls } \\
\hline & BEA & - & BEA & - & BEA & - \\
\hline Day +4 No. 1 & $<10^{2}$ & $<10^{2}$ & $<10^{2}$ & $<10^{2}$ & $<10^{2}$ & $<10$ \\
\hline 2 & $<10^{2}$ & $<10^{2}$ & $10^{7}$ & $<10^{2}$ & $<10^{2}$ & $<10^{2}$ \\
\hline 3 & $10^{7}$ & $<10^{2}$ & $10^{8}$ & $10^{2}$ & $10^{7}$ & $<10^{2}$ \\
\hline 4 & $10^{8}$ & $<10^{2}$ & $>10^{8}$ & $10^{2}$ & $10^{8}$ & 10 \\
\hline 5 & $>10^{8}$ & $10^{3}$ & $>10^{8}$ & $10^{3}$ & $>10^{8}$ & 10 \\
\hline Death/Total & $3 / 30$ & $0 / 30$ & $7 / 30$ & $0 / 30$ & $3 / 30$ & $1 / 30$ \\
\hline Day +8 No. 1 & $<10^{2}$ & $<10^{2}$ & $<10^{2}$ & $<10^{2}$ & $<10^{2}$ & $<10^{\prime}$ \\
\hline 2 & $10^{7}$ & $<10^{2}$ & $10^{5}$ & & $10^{7}$ & \\
\hline 3 & $10^{7}$ & $<10^{2}$ & $10^{7}$ & & $10^{7}$ & \\
\hline 4 & $10^{7}$ & $10^{6}$ & $10^{7}$ & & $10^{8}$ & \\
\hline 5 & $10^{7}$ & $10^{7}$ & $10^{8}$ & & $10^{8}$ & \\
\hline 6 & $10^{7}$ & ND & $10^{8}$ & & $10^{8}$ & \\
\hline 7 & $10^{8}$ & & $10^{8}$ & NĎ & $10^{8}$ & ND \\
\hline 8 & $10^{8}$ & & $10^{8}$ & & $10^{8}$ & \\
\hline 9 & $10^{8}$ & & $10^{8}$ & & $10^{8}$ & \\
\hline 10 & $10^{8}$ & & $10^{8}$ & & $10^{8}$ & \\
\hline Death/Total & $4 / 22$ & $0 / 25$ & $3 / 18$ & $0 / 25$ & $0 / 22$ & $0 / 24$ \\
\hline
\end{tabular}

* $\mathrm{Rx}$ at 0 and day +1 and +7 . 
Since deaths are correlated with elevated BUN values plus large bacterial populations in the kidneys but not with bacterial counts in blood, liver, spleen or bladder or kidneys it is assumed that deaths were due to uremic poisoning.

A number of investigators found that diuresis influences the percent morbidity of infected kidneys in a wide variety of pyelonephritis models and infections ${ }^{1,12 \sim 16,27 \sim 29)}$. FUWA ${ }^{141}$ has also shown that diuresis influences the kidney pathology of BEA. Hence, diuresis via $5 \%$ glucose in the drinking water for three consecutive days was started the day prior to BEA treatment, the day of BEA treatment, the day prior to infection and on the day of the infection. These different regimens put the mice under diuretic conditions during BEA stress and during the localization and establishment of a $P$. mirabilis kidney infection. Table 7 is a representative experiment showing the effect of diuresis on morbidity and mortality in the pyelonephritis model described. Diuresis did not change the bacteriologically negative nature of infected control or BEA control mice and therefore this negative data is only noted in Table 7. From the table it can be seen that diuresis given during BEA stress (day $-3,-2,-1$ ) appears to decrease morbidity if number of positive kidneys are scored on day +7 . However, even though individual kidneys were not harvested on day +15 , the fact that all the mice in this group had bacteriologically positive kidneys indicates that diuresis during preparative stage may incerase the time lag for establishing a kidney infection but does not prevent the development of pyelonephritis. From the data it would appear that diuresis given at other times has little effect on the infectivity of the kidney with $P$. mirabilis.

An experiment in which carbenicillin and ampicillin were tested for efficacy in BEA-stressed mice infected with $P$. mirabilis at $10^{6}$ cells and Pseudomonas at $2 \times 10^{6}$ cells is shown in Table 8. Both antibiotics decreased mortality from both infections. However, while ampicillin appeared efficacious in prolonging the time required to establish a pyelonephritis when $P$. mirabilis was the infecting agent, the antibiotic failed to eliminate the infecting agent. In contrast, carbenicillin appears capable of eliminating an established Pseudomonas infection.

Table 9 gives data from an experiment with a Serratia infection in BEA-stressed and nonstressed mice. It is obvious that BEA-stressed animals more readily develop a localized kidney infection after intravenous inoculation with Serratia than do non-BEA-stressed animals and that neither carbenicillin nor ampicillin had a therapeutic effect.

\section{Discussion}

The normal resistance of the kidneys to bacterial invasion is decreased by a single injection of BEA thus providing a simple laboratory model for studying kidney infections. The data given above show that the model produces consistent kidney infections with a variety of gramnegative organisms. Moreover, the model proposed does not cause a generalized bacterial invasion of other tissues, nor are the deaths which occur due specifically to the number of infecting units populating the kidney (Tables 5 and 6). The deaths appear to result from a uremia perhaps caused by endotoxin when $E$. coli ${ }^{2)}$ is the infecting agent and/or magnesium phosphate calculi when the urease-positive organism, $P$. mirabilis is the infecting agent.

Data presented on the recovery of $P$. mirabilis at various times post-infection (Table 2) show that approximately the same number of inoculated cells lodge in the kidneys of non-stressed mice as in the kidneys of BEA-stressed animals. Hence, any renal pathology from BEA has not resulted in sequestration of the bacteria by the kidneys. However, bacteria that lodge in the kidneys of BEA-stressed mice obviously find the milieu conducive for multiplication since after 
six hours, $70 \%$ of the mice show a 100 -fold increase in numbers of bacteria in their kidneys. In contrast, the bacteria that lodge in kidneys of non-stressed animals do not increase in numbers.

The time recovery studies also indicate that the host resists invasion by the infective agent. This is shown (Table 2) by the reduction in kidney bacterial counts at day 3 and by the ability of the host to prevent the bacterial population from continually increasing in numbers (note day 5, 6, 7 and 8 of Table 2). If the bacterial invader, through its metabolism and/or bacterial products, does not cause irreversible kidney damage, so that uremia and death invervenes, the host can eventually clear its kidneys of the infecting agent (Table 3). However, the host's defense against an established bacterial population in the kidneys is either of a low order of magnitude or slow to develop since $5 \times 10^{5}$ infecting units cause maximum deaths three to five days after the kidney population is maximum. In non-BEA-stressed infection "takes" are spotty and of low frequency, but interestingly, may appear some time after an intravenous infection (Table 4). This is especially true in $P$. mirabilis and Pseudomonas infections.

From the fact that mortality is decreased (Tables 4 and 5) prior to host sterilization of the kidney, it can be deduced that the host inactivated the inimical toxic products of the invader prior to eliminating the invader. The work of Montgomerie, et al. ${ }^{301}$ suggests immune responses could be operating against the endotoxins involved.

The pyelonephritis model proposed would permit the study of a kidney damaged by a severe bacterial infection that has been host eliminated and hence, many of the suggested latent complications of pyelonephritis could be investigated.

The controversy over whether or not diuresis increases infection "takes" or decreases them seems to depend on the infecting organisms plus operative procedures used. Table 7 shows that in this kidney infection model diuresis given during BEA-induced pathology (days $-3,-2$, -1 prior to infection) tends to decrease the rate of kidney infections, if kidneys are examined individually on day +7 . This apparently agrees with FuwA's ${ }^{14)}$ observation that diuresis decreases renal pathology caused by BEA. However, if this same group is examined on day +15 all of the mice were found to harbor bacteria in their kidneys. Hence in this model, diuresis increased the latent period of infectivity but did not prevent the development of pyelonephritis.

In order to determine the in vivo assay value for this kidney model, the antibiotics, carbenicillin and ampicillin (suggested by the work of a number of investigators ${ }^{15,31,32,33,34)}$ ) were tested. The results indicated that in both $P$. mirabilis and Pseudomonas infections both antibiotics had a thrapeutic effect. Ampicillin appears to be more effective in P. mirabilis infections while carbenicillin appears more efficacious in Pseudomonas infections. It was interesting that carbenicillin appears able to erradicate an established infection while ampicillin appears to have more of a restraining effect on the multiplication in vivo. Experiments to establish whether or not the bacteria have become resistant to ampicillin have not yet been done nor have the kidneys been examined for L-forms. The latter may be found in those kidneys cleared of the bacteria by carbenicillin.

BEA initiates a renal pathology conducive to a bacterial infection. This model should be practical for the investigation of therapy directed towards erradicating infections that invade the kidney parenchyma and for investigating the complications that are frequently a latent effect of pyelonephritis.

\section{Acknowledgment}

The excellent technical assistance of Mrs. MARy Alice Parsons is gratefully acknowledged.

\section{References}

1) Andriole, V. T.: Water, acidosis, and experimental pyelonephritis. J. Clin. Invest. 49: 21 30, 1970 
2) Bates, H. M. \& S. Margolin: Endotoxin-induced inhibition of renal function in the mouse. Proc. Soc. Exp. Biol. Med. 129: 642 646, 1968

3) Braude, A. I.; A. P. Shapiro \& J. Semienski: Hematogenous pyelonephritis in rats. I. Its pathogenesis when produced by a simple new method. J. Clin. Invest. 34: 1489 1497, 1955

4) Burrous, S. E. \& J.B. Gacein: Rat pyelonephritis model suitable for primary or secondary screening. Appl. Microbiol. 18: 448 451, 1969

5) English, A. R.; T. J. McBride, L. H. Conover \& P. N. Gordon: 3-Substituted nitrofurantoins as urinary-tract anti-infectives. Antimicr. Agents \& Chemoth.-1966: 434 445, 1967

6) English, A. R.; J.A. Retsema, V.A. Ray \& J.E. Lynch: Carbenicillin indanyl sodium, an orally active derivative of carbenicilin. Antimicr. Agents \& Chemoth. 1: 185 191, 1972

7) Fitzpatrick, F. \& J. Bladzinski: Pyelonephritis in the mouse. No. 3, Therapeutic experiments. Proc. Soc. Exp. Biol. Med. 127: 1180 1185, 1968

8) Fierer, J.; L. Tainer \& A. I. Braude: Bacteremia in the pathogenesis of retrograde E. coli pyelonephritis in the rat. Amer. J. Pathol. 64: 443 454, 1971

9) Fried, F. A. \& R. J. Wong: Etiology of pyelonephritis: Intraductal crystallization as a co-factor. J. Urol. 101: 786 790, 1969

10) Fried, F. A. \& R. J. Wong: Etiology of pyelonephritis: Significance of hemolytic Escherichia coli. J. Urol. 103: 718 721, 1970

11) Fritsche, D.: Investigations into the standardization of acute, experimental ascending urinary tract infections by Bact. Proteus mirabilis in rats. Zentralb. Bakteriol. Parasitenk. Infektionskr. Hyg. 210: $181 \sim 191,1969$

12) Furtado, D. \& L. R. Freedman: Experimental pyelonephritis. XVI. Pseudomonas aeruginosa, Escherichia coli and Staphylococcus aureus infections in mice and effect of "water diuresis". Yale J. Biol. Med. 43: 177 193, 1970

13) Furtado, D.: Effect of diuresis on Staphylococcus aureus kidney infections in mice. Infec. Immunity 4: 742 746, 1971

14) Fuwa, M. \& D. Waugh: Experimental renal papillary necrosis. Arch. Pathol. 85: 404 409, 1968

15) Hubert, E. G.; G. M. Kalmanson \& L. B. Guze: Antibiotic therapy of Escherichia coli pyelonephritis produced in mice undergoing chronic diuresis. Antimicr. Agents \& Chemoth.-1968: $507 \sim 510,1969$

16) Kalmanson, G. M.; E. G. Hubert \& L. B. Guze: Production and therapy of Proteus mirabilis pyelonephritis in mice undergoing chronic diuresis. Antimicr. Agents \& Chemoth.-1969: 458 462, 1970

17) Paplanus, S. H.: Bacterial localization in the kidney. Yale J. Biol. Med. 37: 145 152, 1964

18) Rocha, H.; L. B. Guze, L. R. Freedman \& P. B. Beeson: Experimental pylonephritis. III. The influence of localized injury in different parts of the kidney on susceptibility to bacillary infection. Yale J. Biol. Med. 30: 341 354, 1958

19) Rutsky, E. A.; J.R. Clapp \& R. R. Robinson: Determinants of susceptibility to experimental enterococcal pyelonephritis. Nephron 8: 109 124, 1971

20) Vivaldi, E.; R. Cotran, D. P. Zangwill \& E. H. Kass: Ascending infection as a mechanism to pathogenesis of experimental non-obstructive pyelonephritis. Proc. Soc. Exp. Biol. Med. 102: 242 244, 1959

21) Hill, G.S.; R. G. Wyllie, M. Miller \& R. H. Heptinstall: Experimental papillary necrosis of the kidney. II. Electron microscopic and histochemical studies. Amer. J. Pathol. 68: 213 234, 1972

22) Murray, G.; R. G. Wyllie, G. S. Hill, P. W. Ramsden \& R. H. Heptinstall: Experimental papillary necrosis of the kidney. I. Morphologic and functional data. Amer. J. Pathol. 67: 285 302, 1972

23) Wyllie, R. G.; G. S. Hill, G. Murray, P. W. Ramsden \& R. H. Heptinstall: Experimental papillary necrosis of the kidney. III. Effects of reserpine and other pharmacologic agents on the lesion. Amer. J. Pathol. 68: 235 254, 1972

24) KAYE, D. \& H. Rocha: Urinary concentrating ability in early experimental pyelonephritis. J. Clin. Invest. 49: 1427 1437, 1970

25) Ronald, A. R.; R. E. Cutler \& M. Turch: Effect of bacteriuria on renal concentrating mechanisms. Ann. Intern. Med. 70: 723 733, 1969

26) Marsh, W. H.; B. Fingerhut \& H. Miller: Automated and manual direct methods for the 
determination of blood urea nitrogen. Clin. Chem. 11: 624 627, 1965

27) D’Alessio, D. J.; G. G. Jackson, V. M. Olexy \& C. L. Gantt: Effects of water and furosemideinduced diuresis on the acquisition and course of experimental pyelonephritis. J. Lab. Clin. Med. 78: $130 \sim 137,1971$

28) KAYE, D.: The effect of water diuresis on spread of bacteria through the urinary tract. J. Infec. Dis. 124: 297 305, 1971

29) Levison, S. P. \& D. KAYE: Influence of water diuresis on antimicrobial treatment of enterococcal pyelonephritis. J. Clin. Invest. 51: 2408 2413, 1972

30) Montgomerie, J.Z.; G. M. Kalmanson, E. G. Hubert \& L. B. Guze: Pyelonephritis. Xiv. Effect of immunization on experimental Escherichia coli pyelonephritis. Infec. Immunity 6: $330 \sim 334,1972$

31) Greenwood, D. \& F. O'Grady: Differential effects of benzylpenicillin and ampicillin on Escherichia coli and Proteus mirabilis in conditions simulating those of the urinary bladder. J. Infec. Dis. 122: $465 \sim 471,1970$

32) Homes, K. K.; H. Clark, F. Silverblatt \& M. Turck: Emergence of resistance in Pseudomonas during carbenicillin therapy. Antimicr. Agents \& Chemoth.-1969: 391 397, 1970

33) RifF, L.; V. M. OleXY \& G. G. JACKSON: Therapy with combinations of penicillin analogues in urinary-tract infections. Antimicr. Agents \& Chemoth.-1969: 405 409, 1970

34) Whelton, A.; D. G. Sapir, G. G. Carter, J. Kramer \& W. G. Walker: Intrarenal distribution of penicillin, cephalothin, ampicillin and oxytetracycline during varied states of hydration. J. Pharmacol. Exp. Ther. 179: 419 428, 1971 